\title{
The Origins of American International Retailing: \\ Tiffany of New York in London and Paris, 1837-1914
}

This article considers the international retailing activities of Tiffany of New York between 1837 and 1914. Using data from the company archive alongside other sources, the article considers the firm's international retail operation from entry stage merchant buying activity through to the establishment of modern retailing facilities. The findings indicate five factors were determinants of sustainable international retailing: a centralized organizational structure, a stable ownership structure, existing international engagement, a strong brand identity, and a relevant international retail format. Placing Tiffany's activities in its wider commercial and consumer context, the findings illustrate the organizational changes and asset combination required to support the development of early international retail operations. The article contributes to theoretical understanding of the dynamics of retail internationalization. 
The business history literature generally considers sustained international retailing activity to be a feature of the globalization of markets at the end of the twentieth century. ${ }^{1}$ Management literature encourages this perception; although, the chain store firm of Woolworth, which entered Canada in 1897, the UK in 1909 and Germany in 1926, is acknowledged as the notable exception that proves a general rule. ${ }^{2}$ The accepted narrative for the internationalization of American retailing on a large scale is one of a gradual increase in international retailing activity associated with food retailers and specialist retail firms from the 1960 s onwards. ${ }^{3}$

However, this interpretation does not stand up to close scrutiny. American manufacturing firms were involved in retailing outside the United States from the late nineteenth century, while American retail firms established international buying networks from the mid nineteenth century onwards. Singer, the sewing machine manufacturer, developed an extensive network of agents and retail outlets in foreign markets in the last quarter of the nineteenth century. ${ }^{4}$ Kodak, the photographic materials manufacturer, began opening a chain of European stores in the 1890s. By 1900, its advertising in Europe claimed the firm had stores in London, Liverpool, Glasgow, Paris, Berlin, Brussels, Vienna, St Petersburg and Moscow. ${ }^{5}$ From a buying perspective, large American department store firms such as A.T. Stewart, Marshall Field and Wanamaker imported impressive volumes of goods. ${ }^{6}$ In 1872 , a congressional investigating committee heard that A.T. Stewart was responsible for $10 \%$ of the imports coming through the port of New York. ${ }^{7}$ By 1906: "Marshall Field and Company was paying three-fifths of all customs duties at the Port of Chicago and was the largest importer in the United States". ${ }^{8}$ The scale of their buying encouraged these firms to establish European buying offices. ${ }^{9}$ This international sourcing was fundamental to how they marketed themselves to domestic consumers. However, American department stores did not internationalize in this period.

Given the contribution American chain store retailers such as Woolworth made to the internationalization of retailing in the twentieth century, consideration of nineteenth century international retail activity provides an opportunity to explore those firm level factors that precipitated the internationalization process. That is, how early international retailing activity grew out of the merchant activities of firms such as Tiffany of New York. Tiffany's transition from international merchant to international retailer provides a unique opportunity to investigate those factors that stimulated and supported early retail internationalization. By considering the development of this example of an international retailer over an extended period, it is possible to advance our theoretical understanding of the retail internationalization process. The research reported here addresses the following question: what firm level factors were required to initiate and sustain international retail operations in the late nineteenth century? 
The internationalization of retailing emerged as a distinct research theme in the management literature at the end of the twentieth century. ${ }^{10}$ This literature defines the internationalization of retailing as the transfer of retail technology and concepts, and international retailing as the operation of retail outlets in the domestic market and at least one foreign market. In this literature, international retailing is a forward facing consumer-oriented activity. ${ }^{11}$ It contains three implicit assumptions about international retail firms. First, they are primarily engaged in the retail trade in their domestic and foreign markets. Second, they are large or very large corporations that are shareholder owned. Third, buying activity is not a distinguishing characteristic. These assumptions reflect international retailing activity in the later decades of the twentieth century and early decades of the twenty-first century. However, they are not entirely compatible with earlier examples of international retailing. ${ }^{12}$

First, there is a long history of manufacturing firms with international retail operations. For example, Singer developed an extensive international distribution system by 1914 that was fundamental to the firm's success. ${ }^{13}$ It established an integrated network of international offices where wholesaling and retailing developed side by side. The firm's system of offices and sub-offices protected the brand through sales and service support. Second, international retailing is not entirely the preserve of large publically quoted companies. Research on British retail internationalization has suggested smaller firms might prove a suitable subject for further historical research. ${ }^{14}$ Initial research confirms smaller firms do undertake international initiatives. ${ }^{15}$ Third, the assumption in the management literature that international buying neither defines international retailing nor is it a determinant of international retailing operations is not challenged by the business history literature. In part, this may be a consequence of business historians viewing international retailing as a support function for manufacturing operations. ${ }^{16}$ That is, the manufacturing firm establishes international retail outlets to enhance and control the distribution, selling and servicing of inhouse products. Such a firm does not market products derived from buying operations. From a retail management perspective, lack of evidence to support the role of buying activity as a determinant of international retailing may be a consequence of the organizational structure of large retail enterprises. ${ }^{17}$ That is, the separation of functions may preclude the transfer of international experience across a business. ${ }^{18}$

In the management literature, the causes of international retailing are a mixture of exogenous and endogenous factors. ${ }^{19}$ Exogenous push factors are associated with domestic market saturation and exogenous pull factors are associated with opportunities in host markets. The endogenous factors that motivate firms to internationalize are the strength of the retail brand and distinctiveness of operating format. ${ }^{20}$ Depending on the mix of factors that cause international activity, retailers are categorized as reactive or proactive firms. ${ }^{21}$ Limited opportunities in the home market push reactive firms toward internationalization. Opportunities in the host market pull proactive retailers into international markets. The process of retail internationalization is explained with reference to (i) drivers of change 
within the firm, (ii) the firm's internal facilitating competencies and (iii) the firm's ability to assert control over firm assets within the changing dynamic of the external market environment. ${ }^{22}$ Asset-based and transaction-based drivers of change correspond to Dunning's ownership advantages. ${ }^{23}$ Asset-based advantages derive from the intangible asset of the brand in which the retailer has proprietary rights along with the operating systems and formats used by the firm. The assets are exclusively in the possession of a firm. Asset-based advantages are the result of innovation within the retail firm and are context dependent; that is, they are dependent on characteristics of consumption within the home market. Firms develop these assets in the domestic market and exploit them in foreign markets. In contrast, firms derive transaction-based advantages from the experience of operating international outlets. ${ }^{24}$ Internal facilitating competencies are the means by which the retail firm is able to transfer asset-based ownership advantages and capture transaction-based ownership advantages. Leadership, functional coordination, management experience, and the perceptions and attitudes within an organization, determine the firm's ability to develop international operations. ${ }^{25}$ In the early stages of international activity, a firm will be able to make semi-informed judgements regarding the best way to exploit asset-based advantages. Transaction-based ownership advantages will inform subsequent exploitation of international market opportunities.

This theoretical analysis accommodates twentieth century and early twenty-first century international retailing. However, the importance of manufacturers to the development of international retailing before the second half of the twentieth century has led some business historians to suggest that firms engaged in early international retailing did not possess retail specific asset-based ownership advantages; that is, firms did not have "a strong retail brand or system". ${ }^{26}$ In order to address this question, and determine what firm level factors were required to initiate and sustain international retail operations in the late nineteenth century, it is necessary to consider the retail context in which firms such as Tiffany operated.

\section{Retail Context}

Other American firms provide an instructive benchmark for Tiffany's international retailing activities before 1914. In order to provide context and comparisons, we consider the development of the department store, the chain store and the manufacturer with retail networks. Department stores, such as A.T. Stewart of New York, provide early examples of innovative retail development. The chain store, Woolworth, provides an example of a retail firm that developed international operations at an early date. The manufacturer, Singer, with international retail networks, provides an example of a firm where the primary commercial interest was not retailing. Department stores provide a valuable comparison for the whole of this period. Chain store development is useful as a comparison for the end of the period. Unlike the department stores that began to develop in the middle decades of the nineteenth century, chain stores were a product of the 1890s onward. By the first decade of the twentieth century, department stores had a multi-department structure and occupied large iconic stores. 
In contrast, store chains comprised single unit operations replicated across a market. Operationally department stores combined the role of buyer and retail manager. Chain stores separated these functions thereby facilitating the simplification of the store manager's role and the replication of units within the chain.

Innovation in retailing in the late nineteenth century is associated with large business organizations. The growth of the department store in Britain, France and the United States has generated a wealth of published material. ${ }^{27}$ In this way, and with the help of Zola's literary representation of the French department store at its most dynamic, the department store has come to represent retailing's response to changing economic and social conditions. ${ }^{28}$ Chandler places considerable emphasis on retailing when discussing the emergence of managerial capitalism. He asserts the first "managerial hierarchies appeared during the 1850s and 1860s to coordinate the movements of trains and flow of goods over the new railroad networks ... then quickly came into use to manage the new mass retailing establishments - the department stores, mail order houses, and chains or multiple shops". ${ }^{29}$ Chandler's interpretation places primary emphasis on organizational structure. $\mathrm{He}$ is interested in the scale of the organization and the scope of organizational activities. However, the department stores on which Chandler placed so much emphasis remained domestic operations. In this section, we consider key business characteristics that may have inhibited the internationalization of large retail firms in the late nineteenth century.

Partnerships characterized retail ownership arrangements in the nineteenth century. They were fluid and potentially unstable. A successful partnership could be terminated after an agreed period, usually three years. Partnerships were often based around familial-social relationships and were renegotiated at regular intervals. ${ }^{30}$ Even where the same partners remained in place for some time, agreements were subject to periodic alterations in partner participation and financial investment. American department stores were no exception. ${ }^{31}$ The demise of A.T. Stewart as an independent department store business illustrates the inherent instability of partnership arrangements and associated succession problems. ${ }^{32}$ The history of large American department store firms is punctuated by the arrival and departure of partners. The tensions inherent in any partnership arrangement are illustrated by Selfridge's frustration with his position at Marshall Field. ${ }^{33}$ However, despite the limitations of this ownership structure, American department stores delayed incorporation. Marshall Field \& Company did not incorporate until 1901 and R.H. Macy \& Co did not incorporate until 1919. ${ }^{34}$ In the chain store sector, Woolworth was a syndicate of partner organizations. However, in 1905 following health problems and "concern as to what would happen to his business, and to the men and women of his syndicate, were he ... to decease", Frank Woolworth decided to transform "the structure of his syndicate from an unincorporated company". 35 In a general letter to his employees in February 1905, Woolworth noted, because of incorporation, "no matter what happens to me as President, or to any of the other officers of the company, the business goes on just the same". 36 
In a retailing context, Wilkins' analysis of the importance of intangible assets to international trade, of "brand names, trade names and company names", provides a useful counter-point to the emphasis on organizational structure provided by Chandler. ${ }^{37}$ Whether it is international retailing associated with large manufacturing operations such as Singer or large chain store operations such as Woolworth, brand name, fascia name and/or company name were important assets. They were important in the domestic market but especially important for the transference of innovation to international markets. In international markets, Singer generated increased sales through a distribution system designed to support and protect the brand. ${ }^{38}$ In contrast, department stores did not achieve a clear brand identity across their domestic operation. Certainly, they developed strong company names and the large fixed iconic store was an important marketing tool. For example, Macy's store in New York was the physical representation of the firm's marketing message, a tangible representation of consumer aspiration. However, this asset was neither fully leveraged nor fully appreciated within the firm. In the late 1870s following the death of the firm's founder, Rowland Macy, the remaining partners anticipated changing the firm's name to La Forge \& Valentine from the beginning of January 1879 . Only the sudden death of La Forge prevented this. ${ }^{39}$ In the late nineteenth century, department store firms did not develop a single powerful product based brand identity. ${ }^{40}$ As Lancaster notes: "despite the rise of registered trademarks, the [department] stores themselves created the ethos of the goods sold. The department store with its displays, services and most important, tradition, functioned as the brand". ${ }^{41}$

For large nineteenth century American retailers, international markets were less a retail opportunity and more a sourcing opportunity. From a very early date in their development, American department stores relied heavily on the marketing benefits derived from buying European products. ${ }^{42}$ Alexander Stewart opened a buying office in Paris in $1845 .{ }^{43}$ In 1871 , Marshall Field opened a buying office in Manchester, England, and a Paris office followed in $1872 .^{44}$ International sourcing met the needs of an emerging mass market for which country of origin provided an important indicator of quality and sophistication. The department stores on both sides of the Atlantic responded to this need. As Miller notes with reference to Zola's literary representation of department stores and their impact on the economy and society: "In Zola's vision there was an awareness that a way of life was passing, that with the department store was emerging a society more impersonal, more uniform, more machine-like, more mass-like". ${ }^{45}$ In this, there is a paradox: large American retail businesses were drawn to European markets because they offered sophistication by association for the growing market back home; however, the markets to which they travelled to source goods did not attract international investment until the twentieth century.

The chain store depended on the same factors that drove the development of the department store: higher "levels of capitalization, the volume and type of goods displayed, and the customer base". ${ }^{46}$ However, there was a fundamental difference between the department store and the chain store. By separating the role of retail store manager from retail buyer the chain store firm had an asset, in a replicable retail format, that the department store firm lacked. ${ }^{47}$ The chain store operation was exclusively customer facing. It could be transferred domestically from one town to another and ultimately from one national market to another. 
Woolworth had "318 stores in the United States" when it entered the British market in 1909. ${ }^{48}$ Nevertheless, as Chandler notes, chain stores "did not become a significant retail institution until the first decade of the twentieth century" ${ }^{49}$ Consequently, for large American retail businesses that conform to Chandler's ideal of managerial capitalism expressed through scale and scope, internationalization did not occur until the years immediately before the outbreak of war in Europe in 1914.

Managerial capitalism and the achievement of scale and scope certainly drove major changes in fixed retailing, mail order and wholesaling in the United States market during the late nineteenth century. However, it did not lead to the internationalization of those businesses that epitomized this system. In order to understand the factors that drove retail internationalization, this paper moves the emphasis away from large retail formats to the specialist retailer and the role of the specialist retailer in the development of international retail activity during the second half of the nineteenth century. In this, the firm considered here is a precursor to the American chain stores that internationalized in the twentieth century. In addition, it provides a comparison with department stores that failed to internationalize in the nineteenth century. This paper is concerned with an international specialist retailer that sustained operations in two foreign markets: Britain and France. ${ }^{50}$ Tiffany of New York began operations in Europe in 1850. When Woolworth opened its first store in Britain in 1909, Tiffany already had six decades of international business experience behind it.

Tiffany of New York

The sources available to the researcher interested in nineteenth century history of international retailers are limited. However, Tiffany of New York is a retailer that provides firm level data to support such a study. The firm has been in continuous existence since 1837 . This has facilitated the survival of some nineteenth century internal business records. Where firms have passed through disruptive ownership arrangements or have ceased trading, valuable documentation is often lost. Tiffany \& Co. maintains a professionally managed archive at its offices and operating facilities at Parsippany, New Jersey. The archive primarily serves the commercial requirements of the firm. Consequently, access is restricted. Gaining access was an important stage in the research process. Internal business documents available at the archive provide an opportunity to consider firm structure and strategic decision-making processes. ${ }^{51}$ In addition, we use documentation external to the firm: trade directories, tax records and newspaper advertisements. These documents provide valuable data sources. Used in conjunction with internal archival documents they provide data that firmly date and place events in a way that later commentary or internal business documents may not. Used in combination, these documents provide considerable operational, strategic and marketing insights. Methodologically, using a range of internal and external sources demonstrates how research into early international retail firm activity can be achieved. 
We discuss our findings thematically. That is, we consider those factors that enabled Tiffany to establish and sustain international retail operations during the nineteenth century. Analysis indicates the following themes: a centralized organizational structure, a stable ownership structure, existing international engagement, a strong brand identity, and a relevant international retail format in the context of an expanding consumer market. From our data collection, the following narrative emerged. The first Tiffany retail store opened in 1837 at 259 Broadway, New York. From inception, the store emphasized its international sourcing activities. Partners made buying trips to Europe, particularly Paris, in the 1840s. In 1850, the success of these buying visits led directly to the establishment of a buying office in Paris; at 79 rue de Richelieu. This office was under the management of a new partner, Gideon Reed. By 1868, when the firm incorporated, the original buying office had outlived its usefulness and new premises were found at 57 rue du Cardinal Fesch. ${ }^{52}$ Here a greater emphasis was placed on retailing activity. In 1878, following the firm's success at the Paris Exhibition of that year, Tiffany transferred its operation to a more central and fashionable location at 36bis Avenue de l'Opera. This location was superseded by much larger premises at 3 Place de l'Opera in 1910. Meanwhile, a buying office was opened in London in 1871 at 29 Argyll Street. Increased business led to the transfer to a new office at 5 Argyll Place in 1883. A dedicated retail store opened in 1891 at 221/221A Regent Street. This chronology is included in table 2 later in the article. The factors that contributed to this process and enabled Tiffany to succeed as a pioneering international retailer are discussed thematically below.

The firm's organizational structure was fundamental to its emergence as an early international retail operation. Tiffany maintained a centralized organizational structure throughout the period under consideration. This was due to two factors. First, the leadership structure and entrepreneurial nature of that leadership ensured tight control. One of the original founders of the business, Charles L. Tiffany, was involved in the running of the business until his death in $1902 .{ }^{53}$ The business did not suffer from extended communication channels. The partnership structure provided direct communication between the New York and Paris operations. After incorporation, the board in New York continued to maintain a close relationship with the European operation. Second, the scale of the business was small and scope was narrow. This was neither a business that required elaborate divisional structures nor a business that extended over a wide range of product categories. Certainly, the first catalogue issued by the firm in 1845 shows an eclectic range of goods; however, in the context of the time, these were fancy goods and the firm specialized in them. ${ }^{54}$ As the business developed there was an increasing emphasis on precious stones, silverware, jewelry and watches. ${ }^{55}$ The firm primarily focused on items of high individual value.

\section{Table 1}

The firm's ownership structure supported internationalization as it developed with the changing needs of the business. Charles Tiffany and John B. Young, who had been friends 
since their youth, formed the first partnership in $1837 .{ }^{56}$ A $\$ 1,000$ loan from Charles Tiffany's father provided the capital required to establish the retail business. ${ }^{57}$ Their socialfamilial connections strengthened in 1841 when Charles Tiffany married Young's sister. ${ }^{58}$ However, as the enterprise developed a series of partners joined and left the firm as business needs changed. Table 1 illustrates the temporary and shifting nature of the firm's partnership agreements between the founding of the original business in 1837 and incorporation of the firm in 1868. During this time, the firm had ten partners. Only one, Charles Tiffany, was a partner for the full period of thirty-one years. Following the renegotiation of agreements, partners fulfilled distinct functions. Ellis joined the partnership in 1841 to facilitate John B. Young travelling to Europe to source merchandise for the business. ${ }^{59}$ In 1850 , Gideon Reed joined the partnership to act as the resident partner in Europe to oversee the development of the international operation. ${ }^{60}$ This international partnership structure was fundamental to the first phase of European development. A resident American partner in Paris bridged the gap that might otherwise have existed between the firm in New York and its European operation. Reed's expectations were compatible with those of the remaining partners in New York. He was able to respond to European conditions and support the retailing of goods to expatriate Americans. As a resident partner in Paris, Reed reduced psychic distance for co-partners and customers alike. ${ }^{61}$

Because these partnerships were, by definition, not limited liability arrangements, as the number of partners increased the later agreements attempted to reduce the freedom of action of the junior partners. By the last ten years of the partnership structure, a managerial class emerged, with junior partners' remuneration becoming salaried in form. By the late $1860 \mathrm{~s}$, the firm had grown beyond a partnership structure. On the one hand, the firm needed to bind able managers into the business and on the other it needed to be able to control the liability partnership agreements brought with them. Incorporation provided a framework within which more ambitious international operations could be considered. This was particularly important in a context where the resident partner in Paris had been in place for nearly two decades and the arrangement could not be maintained indefinitely. Continuation of the partnership structure would require an equally able, trustworthy and committed replacement in the event of Reed's retirement.

The firm's resident international office was instrumental in the development of international retail activity. From 1850 to 1868 the office in Paris was located at 79 rue de Richelieu. ${ }^{62}$ Heydt in his brief history of the firm refers to it as "the first branch house" and implies its function was that of buying office. ${ }^{63}$ In the $1850 \mathrm{~s}$, the firm's listing in Paris trade directories confirms the role of "commissionaires" or merchants. ${ }^{64}$ However, it is also clear that the office began to develop a retail function at an early stage. For example, 1863 advertising material published as the "Courrier des hôtels et Guide du commerce réunis" lists "Tiffany, Reed et comp., $79 \mathrm{r}$ Richelieu, ont des demandes d'Amérique en divers art. De haute nouveauté. Vont en magasin". ${ }^{65}$ Aimed at visitors to Paris, this and other advertisements indicate that the rue de Richelieu facility was functioning as a rudimentary retail operation by the 1860s. Consequently, at the first board meeting of the newly incorporated firm, held on Monday 8 June 1868, "it was deemed advisable, to secure another and more desirable 
location, as well as conveniences, for advancing the best interests of the Company" in Paris. ${ }^{66}$ Importantly, "it was also proposed to have constantly on hand a suitable display of goods, adequate to meet the demands of our many friends and customers who may see fit at any time to call upon the Paris House". ${ }^{67}$ The new premises of "Tiffany, Reed \& Co., Paris, rue du Cardinal Fesch, 57" were open for business by Christmas of $1868 .{ }^{68}$ In Gambon's trade directory for Paris in 1873, the firm appears in a list of merchant buying offices "Tiffany, Reed et Cie, bronzes et bijouterie pour leui maison de New-York". ${ }^{69}$ At the rue du Cardinal Fesch the business was still in transition from merchant to retail operation.

This transition from buying office to retail outlet also occurred in London. The firm was sourcing merchandise from London by the early 1870s. For example, Tiffany was agent in the United States for the British watch business of Frodsham. ${ }^{70}$ However, unstable conditions in Paris following the outbreak of the Franco-Prussian war triggered the opening of a London office. Gideon Reed escaped from Paris to London in October 1870 and initially operated from hotel accommodation before an office described as Tiffany, Reed \& Co. "merchants" opened at 29 Argyll Street in late $1871 .^{71}$ The firm transferred to larger office accommodation at 5 Argyll Place in $1883 .{ }^{72}$ However, it was not until 1891 that the firm moved the short distance to 221 and 221A Regent Street in order to operate a dedicated retail outlet. $^{73}$

With the move to Regent Street, buying became a secondary function. A London trade magazine article of the time observes this transition. The article, noting the recent opening of Tiffany's new Regent Street store, emphasizes the impact this would have on nearby jewelers who had benefitted from American visitors to London. The article observes, "a retail trade will be carried on" at the new address whereas before "practically no retail business was done" at the earlier address. ${ }^{74}$ The trade journal continued, "Americans visiting this country often inquired after Tiffany's store", the location of the Argyll Place office meant, "no one could direct them to it". ${ }^{75}$ Employment records confirm that retailing activity had been a business function at the Argyll Place address. ${ }^{76}$ That is, the firm having established an office in London would serve loyal and favored customers despite retailing not being its main or initially intended function. Consumer demand existed in London, just as it had done in Paris, before dedicated retail facilities were available.

This has two important implications for understanding the development of international retail activity at this time. First, retail activity occurred because the firm had a resident international buying office. An office provided an opportunity for the firm to learn, in-market, what customers required of an international retail branch store. Second, a move from one location to another does not necessarily indicate a change in function; rather it indicates the formal recognition within the firm of a changing balance of functions. Therefore, while it may be tempting to see the move to new premises at rue du Cardinal Fesch in Paris (1868) or Regent Street in London (1891) as a definitive demarcation between buying office and retail store, such an interpretation would ignore the subtleties of the development process. Retailing activity preceded these moves and buying activity continued after them. 
The firm's development of a strong brand was crucial to the retail internationalization process. Since its inception, Tiffany had emphasized the quality of its goods through its international sourcing activities. The first catalogue of 1845 explained that merchandise was "of their own importation - made to order, or selected from the best sources, by one of their firm, resident in Europe" ${ }^{77}$ As the business developed, a greater emphasis was placed on the branding, rather than simply the selling, of merchandise. In the early 1870s, in order to ensure merchandise of the highest quality, the firm manufactured watches in Geneva, Switzerland. In 1873, the board decided, "that all watches made by us be only marked Tiffany and Company Geneva, thus adopting the House name as a trade mark". ${ }^{78}$ Incorporation in 1868 was both an important step in the reorganization of the firm and in establishing a consistent identity. However, the European operation continued to trade as Tiffany, Reed \& Co. until Reed's retirement in April 1875. Informed of his intended departure, the board had initially "determined to continue the business in Paris and London under the name of Tiffany Reed and Company, and Mr P.I. de Horrack, and Mr Charles A. Reed" were "appointed joint agents to transact" the firm's "European business". ${ }^{79}$ However, the firm ultimately decided to drop 'Reed' from the name of the operation in Europe and adopt the name used in the United States: Tiffany \& Co. ${ }^{80}$ This act established a consistent brand identity across all markets.

Tiffany's brand positioning was enhanced further by endorsements. This took two forms: royal warrants and the prizes received at World's Fairs exhibitions. In the early 1880s, Tiffany actively sought endorsements from European royal patrons, ${ }^{81}$ while their representation at exhibitions enhanced a reputation for quality that communicated the values of the brand to a wider audience. The success of the brand and its increasing market visibility led directly to the decision to improve retail facilities in Europe. As the firm's catalogue of 1879-80 notes:

"Since the Exposition Universelle at Paris last year [1878], where MESSRS. TIFFANY \& Co.'s goods won the Grand Prize, there has been a continual demand for their wares in Europe, and to facilitate the growing foreign business they have removed their Paris house to the more central and accessible location - Avenue de l'Opera $36^{\text {bis }}$, which is the only place besides the Union Square [New York] establishment where their goods can be purchased, as they are never sold to dealers". ${ }^{82}$

This statement is significant for two reasons: it illustrates the prominence achieved by the Tiffany brand and it emphasizes the close relationship between brand as product and brand as an in-house retail-service experience.

The firm's ability to respond to changing market conditions with format development and innovation was fundamental to establishing a sustainable international retail operation. The establishment of the London store in 1891 and the Paris store in 1910 illustrate the firm's response to changing market conditions and the recognition of the need for an international retail format. These two innovations are discussed below.

The first Tiffany store in London provided access and assortment not previously available to customers. A London based trade journal, The Watchmaker, Jeweller and Silversmith, noted 
in its 1 July 1891 edition: "the American store is now located in Regent street". ${ }^{83}$ Before moving into the new premises, Tiffany combined two shops and through its improvements increased the gross estimated rental value of the property by $70 \% .{ }^{84}$ Heydt suggests that at the time he was writing (1893) "the London house occupies a handsome store at 221 and 221A Regent Street, where a large assortment of Tiffany \& Co.'s products are always kept in stock". ${ }^{85}$ The store carried a specialist merchandise range. Store window advertising describes a jeweler, selling precious stones. ${ }^{86}$ Sales to customers show the store had a particularly strong trade in jewelry items such as bracelets, brooches, necklaces, pendants, rings and tiaras, along with purses and watches. ${ }^{87}$ Advertising shows the firm specialized in jewelry, watches, silverware and objects of art. ${ }^{88}$ Photographs of the store, from 1898 and 1910, depict a four-story building, with a street-level store frontage. ${ }^{89}$ The fascia emphasizes the firm's international profile: New York and Paris. On the corner of Maddox Street and Regent Street, it occupied a prominent location on one of London's most prestigious retail thoroughfares. It was opposite Liberty's main store, which was then on Regent Street.

The headquarters of the European business remained in Paris. However, the Paris operation at the Avenue de l'Opera was becoming inadequate for dealing with increasing consumer demand. Relocation to the Avenue de l'Opera in 1878 placed the Paris operation in a more central and fashionable position. However, the new location did not have facilities at ground floor level directly accessible from the street. ${ }^{90}$ This became a major limitation of the business. The sales area was on the first upper story, providing a discrete selling space for loyal customers. It was in many respects appropriate for the sale of the high value items: diamonds, jewelry, watches and American silverware. ${ }^{91}$ However, as the firm's potential market grew, the limited retail sales space at the Avenue de l'Opera prompted the firm to obtain accommodation more accessible to passers-by. ${ }^{92}$ On 4 October 1905 , the board sent a letter to Messrs Tiffany \& Co. Paris indicating that:

"During his last visit to Paris, Mr Louis C. Tiffany was much impressed with the advantages the local jewelers there possess in having their salesrooms on the ground or street level. Everyone visiting Paris devotes more or less time to looking at the wares displayed in the shop windows, and the convenience and ease with which one can step into a shop on the street level to examine and price goods undoubtedly lead to many sales which are - though being located on an upper floor - lost". 93

The firm had been keen to respond to market needs for some time, this was not the first time this development had been considered; however, "a suitable place has never been available". ${ }^{94}$ The Paris house was a complex operation by the beginning of the decade, with 29 members of staff in various roles. ${ }^{95}$ Initially Louis Comfort Tiffany suggested securing the shop on the ground floor of the building in which the firm already operated, 36bis Avenue de l'Opera. The Paris branch cabled the board in New York on 20 November 1905 to inform them, the "Tourist shop control lease until July 1912, rental Frs 25000.- per year". ${ }^{96}$ But it soon became evident to the board that merely expanding into the ground floor of the existing branch would be insufficient. By early 1906, the board's plans for the Paris store had become more ambitious. The Equitable Life Assurance Society of New York, Tiffany's landlord in Paris, was to offer the firm a more prestigious site with a larger sales area close by: that is, 
"the ground floor, entre-sol, first floor and basement of their building at rue de la Paix and Avenue de l'Opera". ${ }^{97}$ The lease was to be for twenty-four years commencing 1 April 1907 at an annual rental of 200,000 francs. ${ }^{98}$ However, the rental cost was to increase further and substantially. Minutes of the board taken on 15 January 1907 indicate improvements by the Equitable would result in a more expensive lease, amounting to a higher rent of 325,000 francs per year. ${ }^{99}$ The board was clearly prepared to countenance this higher cost, giving "Mr C.M.Moore, manager of the Paris House" negotiating power "to make the best arrangement possible for the changes in Contemplation". ${ }^{100}$ The new store was an ambitious undertaking. This is reflected in contemporary accounts of the store's development. ${ }^{101}$ The Daily Trade Record New York details the length to which the architects and designers were willing to go to ensure the most effective store possible. The newspaper notes, "before work on the store itself was begun a full-size model in plaster, showing a section of the store as it now appears, was set up in one of the suburbs of Paris". ${ }^{102}$

Tiffany's retail operation in Paris changed from being an upper story salesroom to a new type of international store. The New York Herald, Paris edition, ran a long feature on it on Sunday 24 April 1910: "the new shop is constructed on lines entirely different from those employed in the typical jewelry shop in European cities. Its novelty its artistic beauty and its conveniences for customers set it apart from even the most famous places of its kind, and make it one of the show places of Paris." "103 It had "360 square metres of floor space": an extravagant use of empty space was expressed through "the broad transverse space running across from the boulevard to the rue de la Paix, and two broad aisles extending to the back". ${ }^{104}$ However, it was also a practical sales environment designed to engage the customer's attention, because "the most striking feature of Tiffany's, certainly the most novel to Parisians, is the system of show-cases". Here greater customer access to merchandise replaced the secluded upper story showroom. That is, "instead of articles of jewelry being brought out from safes and displayed one by one on a table before the prospective purchaser, all the articles for sale are exhibited in the familiar American way, in a series of glass and bronze show-cases". There is enticement, encouragement to engage with the merchandise without the immediate and potentially discouraging interaction with employees, because "visitors may enter the store, wander from case to case at their leisure ... or merely enjoy the splendid display". ${ }^{105}$ Here, the store is a tourist destination in its own right, a display case for the brand.

This iconic store was the firm's response to an expanding consumer market. For example, the pricing system at the Place de l'Opera store encouraged purchases at modest sums as well as extravagant prices: "any sum from 25 to $1,000,000 \mathrm{fr}$ ". ${ }^{106}$ During the period under consideration, two changes occurred in the firm's customer base. First, the firm became less dependent on expatriate Americans. Secondly, a wider group of consumers was encouraged to patronize the international stores. Commentary on Tiffany's customer base has emphasized the expatriate American. ${ }^{107}$ There appears little question that American visitors were encouraged to visit the firm's European operations. Paris was an important destination for Americans visiting Europe in the years following the Civil War. ${ }^{108}$ Likewise, the London store sought to address the requirements of American customers. Advertisements from the 
late 1890s provide "dates for delivering Christmas Presents in the United States". 109 However, internal firm records show that by the 1910s English customers along with expatriate American customers were purchasing from the Regent Street store. ${ }^{110}$ In Paris, the new 1910 store on the Place de l'Opera was "not only for Americans but for Parisians themselves". 111

Between 1850 and 1910, per capita GDP in France almost doubled. ${ }^{112}$ Changes to Tiffany's operation in the Paris market reflect this increase in spending power. Initially retailing was an incidental outcome of Tiffany's buying office in Paris and was a service provided for visiting Americans. By the 1910s, the firm had established an iconic retail store in a fashionable location designed to appeal to a new consumer base. Similarly, Tiffany's changing operation in London is a reflection of the move away from a restricted group of American customers travelling in Europe to an emerging indigenous market and widening consumer base. When Tiffany started buying in Europe in the 1840s, Paris was the most attractive market for the firm's merchant activities. When the firm opened its Regent Street store in 1891, France's per capita GDP was only $60 \%$ of the United Kingdom's. ${ }^{113}$ Tiffany's ability to develop its retail format over this sixty-year period in two major European cities is indicative of a firm with the organizational capabilities to respond to changing consumer demand.

\section{Discussion}

This article addresses the following question: what firm level factors were required to initiate and sustain international retail operations in the late nineteenth century? Tiffany's international retail operation developed as the result of a combination of factors that came together at a relatively early date. They were a centralized organizational structure, a stable ownership structure, existing international engagement, a strong brand identity, and a relevant international retail format. In the context of an expanding consumer market, these factors facilitated the initiation and development of sustainable international retailing activity.

Tiffany operated through a centralized organizational structure. The scale of the business was not large. The international business was a buying operation that developed a retail function. In time, the retail function became dominant. The firm's organizational structure provided a simple platform for the management of the retail operation. Had department stores tried to replicate their stores internationally, they would have been on a very different scale and required extensive integration with local distribution and supplier systems. In contrast, Tiffany's organizational structure facilitated the development of international stores.

Charles L. Tiffany and Gideon Reed provided continuity of leadership and strategic direction for a long and important period in the firm's development. In particular, Gideon Reed had a crucial role in the establishment of the international operation. Within the ownership structure provided by partnership agreements, Reed established a branch office in Paris that laid the foundations for future European development. However, the partnership structure inevitably 
led to shifting arrangements that could potentially destabilize the business. With incorporation, there was a fundamental change in the level of international engagement. The history of A.T. Stewart's department store is an example of what could happen to a business on the death of the key entrepreneurial innovator. ${ }^{114}$ Lacking direction and appropriate ownership arrangements, the business went into terminal decline. This is indicative of the instability associated with partnerships and unincorporated businesses. Partnerships remained a feature of large American department stores long after Tiffany incorporated. Incorporation balanced the value of strong individual leadership within the centralized organizational framework of the firm. Incorporation was clearly an important factor in Tiffany's willingness to engage with further international growth.

From its earliest years as a retailer in New York, international sourcing defined Tiffany's merchandise range. John B. Young's regular buying trips to Paris in the 1840s were indicative of partners' commitment to this aspect of the firm's commercial identity. This merchant activity drew the firm into international markets and gave it an increasing knowledge of them. The establishment of an international resident buying office proved fundamental to Tiffany's recognition of the retail potential available in international markets. With this, the retail business could grow incrementally. A buying office provided local knowledge and market understanding. The existence of the office facilitated the development of transaction-based assets. Tiffany was not the only American retail firm that engaged in international sourcing in the second half of the nineteenth century. The department store sector actively and extensively sourced in European markets. However, the size of department store organizations may have inhibited knowledge transfer across business functions as strategic decision-making became isolated from the knowledge accrued within the organization's functional units. In contrast, at Tiffany, buying and retailing were centralized, so knowledge derived from one activity could easily transfer to another.

From 1875, Tiffany had a consistent and clearly defined brand across its domestic and international markets. The firm took full advantage of this asset-based advantage. The ending of the partnership structure facilitated this, as did the development of retail formats suited to international markets. In this, Tiffany created a clear and consistent brand identity with regard to both the product and service environment. Exclusively selling products through its own retail outlets further enhanced this relationship. In contrast, department stores did not have clear and consistent own brands. They had a fragmented brand architecture spread across a wide range of product qualities and categories. Woolworth, as representative of chain stores, had a recognizable fascia and identity. However, the firm did not have a strong product own brand that built on its retail identity. In contrast, Singer, as representative of a manufacturer with a retail network, had a distinct, strong brand consistent with the identity of its retail system. From a branding perspective, Tiffany resembled the manufacturing firm of Singer more than it resembled other retailers. The creation of a distinct brand was fundamental to Tiffany's international development, whether from the perspective of American consumers wanting the security of buying from a familiar firm when travelling abroad or from the perspective of European consumers recognizing a desirable brand. As a 
retailer, Tiffany was innovative by placing a distinctive brand and coherent brand message at the center of its marketing activities.

For the process of retail internationalization in the late nineteenth century, scale could be an asset but scope was a liability. Trading name, fascia and brand proved fundamental to firm success. Woolworth and Singer used their organizational capabilities and scale to establish their dominant presence in host markets. However, neither firm built their international operations on the scope of their activities. Certainly, Woolworth sold merchandise in different categories but the firm did not do so to the same extent and on the same basis as the department stores. Likewise, Woolworth did not combine buying and selling functions in the same way as the department stores. Singer's distribution system emphasized a narrow product focus. Singer and Woolworth possessed a strong brand or company name and both developed a distribution system and retail format that facilitated replication. In contrast, the department stores were built on scale and scope but did not develop the same brand asset and a replicable retail format. Instead, they sold manufacturer brands and developed various captive brands. This was in contrast to Tiffany that did possess a distinct brand. Tiffany's organizational structure and merchandise range facilitated this. The firm's development of a single brand strategy and the marketing of Tiffany goods exclusively through its own retail outlets domestically and internationally was a valuable commercial asset.

Table 2

Tiffany's retail activities in Paris and London underwent considerable development between the arrival of a resident partner in Europe in 1850 and the opening of the firm's iconic store format in Paris in 1910. In this, the firm's retail operations grew with the opportunities provided by the markets of London and Paris. The store development process indicates Tiffany went through three phases of international retail activity (see table 2). Initially retail activity was carried out through the international office which was established for buying activity. This was the merchant phase. This was followed by a period of proto-modern international retailing activity. In this phase, the firm's facilities retained some of the older characteristics of the merchant operation with new customer facing activities: a buying office and discrete retail facilities designed to serve a narrow customer base. In this proto-modern phase, the firm transitioned from a merchant operation to a fully developed retail operation. This transition culminated in a modern retail offering as represented by the 1891 London store and the 1910 Paris store. Modern retail facilities provided street-level open access and an internal open display of merchandise. For Tiffany, these facilities provided a showcase for a distinct and consistent brand identity. In this combination, a consistent brand identity and modern facilities represented a major development in the firm's retail provision and was a clear acknowledgement of the changing needs of its widening customer base. This incremental development shows the firm acquired transaction-based assets during its time in international markets. 
Conclusion

The process of retail internationalization in the late twentieth century and early twenty-first century is explained in the management literature by firm drivers of change, internal facilitating competencies and the assertion of control over firm assets. However, this literature has not shown how this process occurs over an extended period within a changing market context. The research presented here addresses this gap in the literature by considering the firm level factors required to develop and sustain international retail operations during the late nineteenth century.

Tiffany's activities in European markets illustrate the firm's use of asset-based advantages derived from the firm's brand, operating systems and formats. Initially, these were assetbased advantages derived from innovation within the retail firm in the domestic market. These assets were developed in the domestic market and exploited in foreign markets to serve a consumer group familiar with the firm's domestic operations. However, Tiffany's development of transaction-based advantages derived from the experience of operating international outlets was to transform fundamentally the firm's ability to operate in and respond to international markets. Tiffany's development of internal facilitating competencies enabled the firm to transfer asset-based ownership advantages and capture transaction-based ownership advantages. Functional coordination between buying and retailing activity facilitated the development of the latter during the firm's merchant phase. Functional coordination and strategic decision makers' knowledge of these functions continued to support international retail development throughout the period. The firm built on international management experience and this determined its ability to develop successful and sustainable international operations. The firm did not launch a retail store in the Paris market without first developing transaction-based ownership advantages. These informed subsequent expansion in London. This article contributes to the literature by showing how this process works over an extended period of more than sixty years, across two international markets.

The management literature makes three implicit assumptions about international retail firms: they are primarily engaged in the retail trade in their domestic and foreign markets, they are large or very large corporations that are shareholder owned, and sourcing activity is not a distinguishing characteristic. This reflects international retailing activity at the end of the twentieth century and beginning of the twenty-first century. The business history literature has questioned the first assumption, that firms engaged in international retailing are primarily engaged in the retail trade in their domestic and foreign markets. In the business history literature, manufacturing firms are seen as drivers of retail internationalization before 1960 . However, the findings reported here show that international retailing was associated with a retail firm from a very early date. The second assumption, that international retailing is the preserve of large or very large corporations that are shareholder owned, is qualified by the findings presented here. They show a centrally organized, specialist, smaller firm was well 
placed to respond to international retail opportunities and it was better placed than larger contemporary firms of greater scale and scope. The findings also suggest the retail internationalization process is reliant on an appropriate ownership structure and that incorporation and internationalization occur during the same phase of development. The third assumption, that sourcing activity is not a distinguishing characteristic of international retailing, is challenged. In the management literature, international retailing has been conceptualized as a consumer facing activity and not a distribution channel process. However, as this study shows, sourcing can have a fundamental impact on the initiation of international retailing activity.

The management literature indicates a mixture of exogenous and endogenous factors cause international retailing. That is, where international market opportunities motivate proactive retail firms to internationalize on the strength of their distinct retail brand and operating format. Tiffany was pulled into international markets through increasing consumer demand for its retail offering, and has the characteristics of a proactive retailer. However, unlike post1960 examples of retail internationalization, the firm did not arrive in those markets with a fully developed brand identity nor with a distinct operating format derived from operations in the domestic market. Therefore, this research qualifies previous understanding of the internationalization process and places an emphasis on transaction-based advantages derived from international activity rather than asset-based advantages derived from operations in the domestic market.

In the United States, in the second half of the nineteenth century, the department store has defined the modernization of fixed store retailing. However, the department store did not become a vehicle for retail internationalization through the direct transfer of technology and concept. Indeed, even in the domestic market it proved difficult to replicate. The scope of the department store enterprise ultimately precluded replication. This study of Tiffany of New York shows that a smaller specialist retail organization was well suited to early internationalization. Brand identity, incremental international store development and awareness of changing consumer needs were important drivers of international retail activity at a very early date. Proactive retailers are able to expand internationally because of their brand relevance and distinctive retail format. The early history of Tiffany is a good example of this. This research shows it was not scale and scope that initiated early American international retailing, it was brand and focus. 
NICHOLAS ALEXANDER is Professor of Marketing at Lancaster University Management School, Lancaster University, United Kingdom. His research is in the area of international marketing, branding and business history. He is currently researching the history of retail internationalization.

ANNE MARIE DOHERTY is Professor of Marketing at Strathclyde Business School, University of Strathclyde, United Kingdom. Her research is in the area of international retail marketing, particularly market entry methods, franchising and retail internationalization in emerging markets. She is currently researching the history of retail internationalization. 
Table 1. Tiffany Partnership Agreements 1837-67

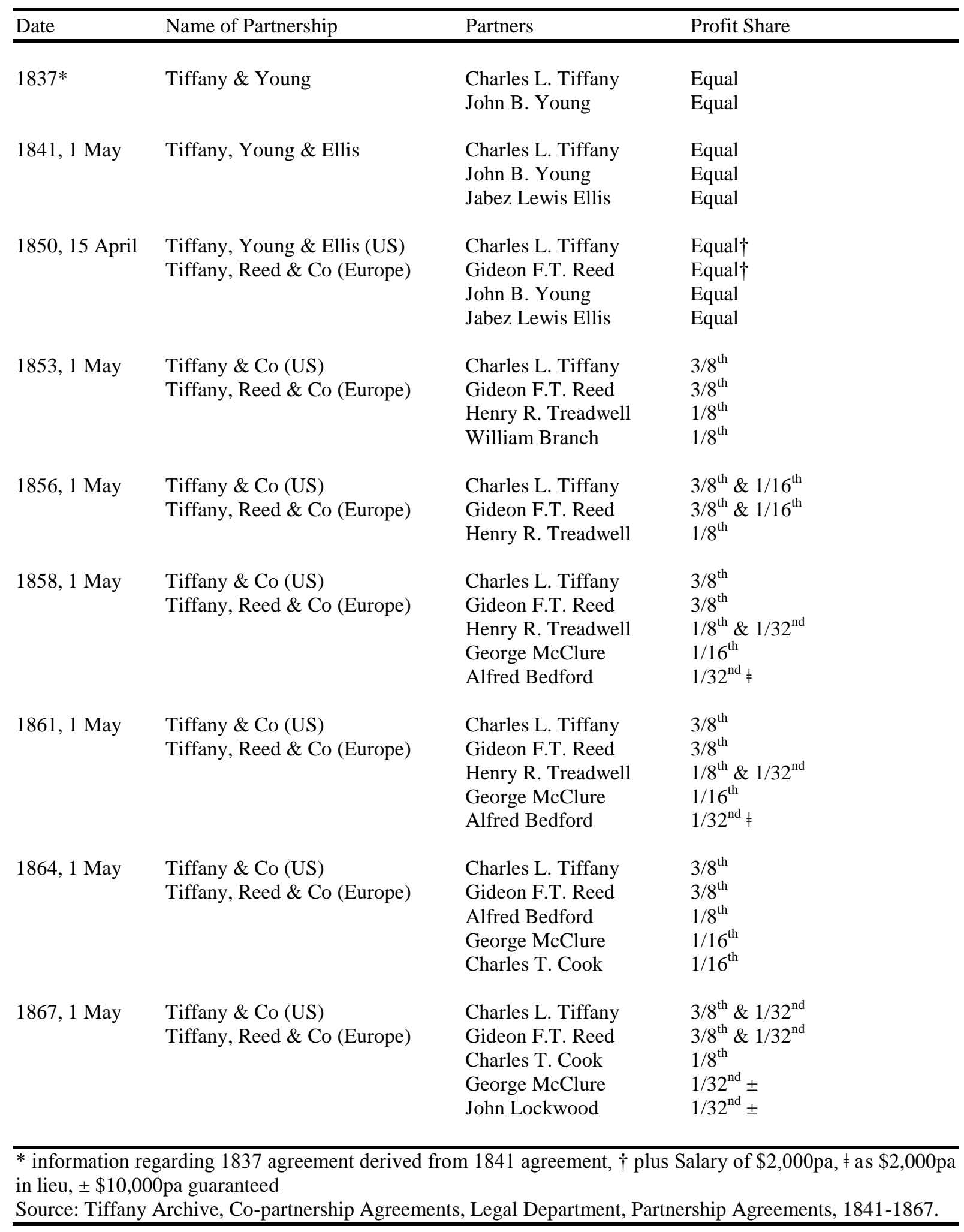


Table 2. Evolution of Tiffany's International Operation: 1837-1914

\begin{tabular}{|c|c|c|c|c|}
\hline Stage & Paris & London & Operational Functions & Notes \\
\hline \multicolumn{5}{|c|}{ Merchant Activity } \\
\hline Ia & Address(es) unknown: 1840s & Langham Hotel: 1871 & Buying activities & $\begin{array}{l}\text { Distinguishing selling point in } \\
\text { domestic market }\end{array}$ \\
\hline $\mathrm{Ib}$ & 79 rue de Richelieu: $1850-68$ & $\begin{array}{l}29 \text { Argyll Street: } 1871 / 2-82 \\
5 \text { Argyll Place: } 1883-91\end{array}$ & $\begin{array}{l}\text { Primary: Resident buying office } \\
\text { Secondary: Ad hoc retailing }\end{array}$ & Resident partner in Europe: 1850 \\
\hline \multicolumn{5}{|c|}{ Proto-Modern International Retailing Activity } \\
\hline IIa & $\begin{array}{l}57 \text { rue du Cardinal Fesch/ } \\
\text { de Châteaudun*: 1868-78 }\end{array}$ & Not applicable & $\begin{array}{l}\text { Equal: Salesroom retailing } \\
\text { Equal: Resident buying office }\end{array}$ & $\begin{array}{l}\text { Incorporation: } 1868 \\
\text { Adoption of international brand: } 1875\end{array}$ \\
\hline $\mathrm{IIb}$ & $\begin{array}{l}\text { 36bis Avenue de l’Opera: } \\
\text { 1878-1910 }\end{array}$ & Not applicable & $\begin{array}{l}\text { Primary: Salesroom retailing } \\
\text { Secondary: Resident buying office }\end{array}$ & $\begin{array}{l}\text { Brand recognition at the } \\
\text { Paris Exhibition of } 1878\end{array}$ \\
\hline Modern & International Retailing Activit & & & \\
\hline IIIa & Not applicable & $\begin{array}{l}\text { 221/221A Regent Street: } \\
\text { 1891-1914 }\end{array}$ & $\begin{array}{l}\text { Primary: Ground floor, open access retailing } \\
\text { Secondary: Resident buying office }\end{array}$ & $\begin{array}{l}\text { Emergence of an indigenous } \\
\text { clientele at international locations }\end{array}$ \\
\hline $\mathrm{IIIb}$ & 3 Place de l’Opera: 1910-14 & Not applicable & $\begin{array}{l}\text { Primary: Iconic store concept } \\
\text { Secondary: Resident buying office }\end{array}$ & $\begin{array}{l}\text { Creation of an international } \\
\text { retail-brand concept }\end{array}$ \\
\hline
\end{tabular}




\section{Acknowledgements}

We would like to thank Annamarie Sandecki and Amy McHugh for providing access to the Tiffany Archive, Parsippany, NJ. Their help and advice is much appreciated.

${ }^{1}$ Geoffrey Jones, Multinationals and Global Capitalism: From the Nineteenth to the Twenty-First Century (Oxford, 2005).

${ }^{2}$ Stanley C. Hollander, Multinational Retailing (East Lansing, Mich., 1970).

${ }^{3}$ Madhav P. Kacker, Transatlantic Trends in Retailing: Takeovers and Flow of Know-How (Westport, Conn., 1985).

${ }^{4}$ Mira Wilkins, The Emergence of Multinational Enterprise (Cambridge, Mass., 1970), 43-44; Andrew Godley, "Foreign Direct Investment in British Manufacturing," The Business History Review 73, 3 (1999): 394-429.

${ }^{5}$ The Graphic (London, England), Saturday, 1 December, 1900, 824.

${ }^{6}$ Harry E. Resseguie, "Alexander Turney Stewart and the Development of the Department Store, 1823-1876," The Business History Review 39, 3 (1965): 301-322; Robert W. Twyman, The History of Marshall Field and Company, 1852-1906 (Philadelphia, Pa., 1954); Herbert Gibbons, John Wanamaker Vols. I and II (New York, 1926).

${ }^{7}$ Harry E. Resseguie, "The Decline and Fall of the Commercial Empire of A. T. Stewart," The Business History Review 36, 3 (1962): 255-286, $256 \mathrm{n} 3$.

${ }^{8}$ Twyman, The History of Marshall Field, 99.

${ }^{9}$ Resseguie, “Alexander Turney Stewart”; Twyman, The History of Marshall Field; Gibbons, John Wanamaker.

${ }^{10}$ Nicholas Alexander, International Retailing (Oxford, 1997).

11 John Dawson, "Internationalization of Retailing Operations," Journal of Marketing Management 10 (1994): 267-82.

12 Nicholas Alexander, "British Overseas Retailing, 1900-60: International Firm Characteristics, Market Selections and Entry Modes," Business History 53 (2011): 530-556.

13 Andrew Godley, "Selling the Sewing Machine Around the World: Singer's International Marketing Strategies, 1850-1920", Enterprise \& Society, 7, 2 (2006); Wilkins, The Emergence of Multinational Enterprise.

${ }^{14}$ Alexander, "British Overseas Retailing, 1900-60": 552.

${ }^{15}$ Anne Marie Doherty and Nicholas Alexander, "Liberty in Paris: International retailing, 1889-1932”, Business History, 57, 4 (2015): 485-511.

${ }^{16}$ Andrew Godley, "Foreign Multinationals and Innovation in British Retailing, 1850-1962," Business History 45, 1 (2003): 80-100.

${ }^{17}$ Irena Vida, James Reardon and Ann Fairhurst, "Determinants of International Retail Involvement: The Case of Large U.S. Retail Chains,” Journal of International Marketing 8, 4 (2000): 37-60.

${ }^{18}$ Kent Eriksson, Jan Johanson, Andres Majkgard, and D. Deo Sharma "Experiential Knowledge and Cost in the Internationalization Process,” Journal of International Business Studies 28 (1997): 337-60.

${ }^{19}$ Kacker, Transatlantic Trends.

${ }^{20}$ Alexander, International Retailing.

${ }^{21}$ Peter McGoldrick and Gary Davies, International Retailing: Trends and Strategies (London, 1995).

${ }^{22}$ Nicholas Alexander and Hayley Myers, "The Retail Internationalisation Process," International Marketing Review 17 (2000): 334-53.

${ }^{23}$ John Dunning, International Production and the Multinational Enterprise (London, 1981). John Dunning, "The Eclectic Paradigm of International Production: A Restatement and Some Possible Extensions," Journal of International Business Studies 19, 1, (1988): 1-31.

${ }^{24}$ Dunning, "The Eclectic Paradigm".

${ }^{25}$ Irena Vida and Ann Fairhurst, "International Expansion of Retail Firms: A Theoretical Approach for Future Investigations," Journal of Retail and Consumer Services 5, 3 (1998): 143-51.

${ }^{26}$ Andrew Godley and Haiming Hang, "Globalisation and the Evolution of International Retailing: A Comment on Alexander's 'British Overseas Retailing, 1900-1960',' Business History 54, 4 (2012): 529-541.

${ }^{27}$ John William Ferry, The History of the Department Store (Macmillan: New York, 1960), 244, $305,312$. Gibbons, John Wanamaker; Ralph M. Hower, History of Macy's of New York 1858-1919 (Cambridge, Mass., Harvard University Press, 1943); Bill Lancaster, The Department Store: A Social History (London, 1995), 86; Michael B. Miller, The Bon Marché: Bourgeois Culture and the Department Store, 1869-1920 (Princeton, New Jersey, 1981), 119; Hrant Pasdermadjian, The Department Store, Its Origins, Evolution and Economics (London, 1954); Resseguie, "Alexander Turney Stewart"; Resseguie, "The Decline and Fall"; Twyman, The History of Marshall Field, 175. 
${ }^{28}$ Émile Zola, The Ladies Paradise (Oxford, reprinted 1995).

${ }^{29}$ Alfred D. Chandler, Jr., "The Emergence of Managerial Capitalism," The Business History Review 58, 4 (1984): 473-503, 474.

${ }^{30}$ Naomi R. Lamoreaux, "Constructing Firms: Partnership and Alternative Contractual Arrangements in Early Nineteenth-Century American Business," Business and Economic History 24, 2, (Winter 1995): 43-71; Eric Hilt and Katherine O'Banion, "The Limited Partnership in New York, 1822-1858: Partnerships without Kinship," The Journal of Economic History 69, 3 (2009): 615-645.

${ }^{31}$ Ferry, The History of the Department Store.

${ }^{32}$ Resseguie, "Alexander Turney Stewart"; Resseguie, "The Decline and Fall".

${ }^{33}$ Twyman, The History of Marshall Field.

${ }^{34}$ Ferry, The History of the Department Store, 61, 133.

${ }^{35}$ John P. Nichols, Skyline Queen and the Merchant Prince: The Woolworth Story (New York, 1973), 65.

${ }^{36}$ Ibid. 66.

${ }^{37}$ Mira Wilkins, "The Neglected Intangible Asset: The Influence of the Trade Mark on the Rise of the Modern Corporation,” Business History 34, 1 (1992): 66-95, 66.

${ }^{38}$ Paula de la Cruz-Fernández. "Multinationals and Gender: Singer Sewing Machine and Marketing in Mexico, 1890-1930," The Business History Review 89, 3 (2015): 531-549. Godley, "Selling the Sewing Machine Around the World".

${ }^{39}$ Hower, History of Macy's, 158.

${ }^{40}$ According to Bill Lancaster it was not until the 1920s that they developed strong product based single brand identities. Lancaster, The Department Store, 88.

${ }^{41}$ Ibid.

${ }^{42}$ As early as 1852, during the time he ran a dry goods store at Haverhill and before moving to New York, Rowland Macy advertised "English, French and American" dry goods were available in his store. Hower, History of Macy's, plate between pages 20 and 21.

${ }^{43}$ Resseguie, "Alexander Turney Stewart".

${ }^{44}$ Twyman, The History of Marshall Field, 27, 99.

${ }^{45}$ Miller, The Bon Marché, 190.

${ }^{46}$ Mark Casson and John S. Lee, "The Origin and Development of Markets: A Business History Perspective," The Business History Review 85 (2011), 9-37, 19. Lancaster, The Department Store, 86.

${ }^{47}$ Woolworth store managers selected merchandise from an approved list provided by the firm's central buying operation. John P. Nichols, Skyline Queen and the Merchant Prince: The Woolworth Story (New York, 1973), 38.

${ }^{48}$ Alfred D. Chandler, Jr., The Visible Hand (Cambridge, 1977), 234.

${ }^{49}$ Chandler, The Visible Hand, 233.

${ }^{50}$ The firm had a store in Geneva for a short time in the 1870s. It was associated with Tiffany's watch factory and did not survive the closure of the factory.

${ }^{51}$ A brief 1890 s account of Tiffany's early history by George Frederic Heydt provides early commentary on the firm's development: George Frederic Heydt, Charles L. Tiffany and the House of Tiffany \& Co. (New York, N.Y., 1893). This source confirmed the firm as a suitable subject. Similarly, material such as Purcell's commentary in a Tiffany exhibition catalogue of 2006, further supported the choice of this firm: Katherine Purcell, "Tiffany and Paris 1850-1910", in Bejewelled by Tiffany 1837-1987, ed. Clare Phillips (New Haven, Conn., 2006), 26-45.

${ }_{52}$ After the Franco-Prussian war of 1870-71 the rue du Cardinal Fesch was renamed rue de Châteaudun.

${ }^{53}$ Charles L. Tiffany died February 1902: Charles L. Tiffany Obituary, New York Times (New York) 19 February 1902: 3a.

${ }_{55}^{54}$ Tiffany Catalogue, printed 1845, Tiffany Archive, Parsippany, N.J.: hereafter, TA.

55 Co-partnership agreements, Legal Department, Partnership Agreements, 1850-1864, TA; Incorporation document, 1868, TA.

${ }^{56}$ John B. Young is described as Charles Tiffany's "neighbour, friend and schoolmate" in Heydt, Charles L. Tiffany, 9.

${ }^{57}$ New-York Tribune, 19 February, 1902: 3a.

${ }^{58}$ Ibid.

${ }^{59}$ Ibid

${ }^{60}$ Partnership agreement, 15 April 1850, TA; Partnership agreement, 1 May 1856, TA.

${ }^{61}$ For a recent discussion of psychic distance in the retail business history literature, see: Haiming Hang and Andrew Godley, "Revisiting the Psychic Distance Paradox: International Retailing in China in the Long Run (1840-2005)," Business History 51, 3 (2009): 383-400.

${ }^{62}$ Heydt, Charles L. Tiffany, 18. 
${ }^{63}$ Ibid.

${ }^{64}$ Annuaire Général du Commerce, Paris, Didot Frères, 15e Année de la publication, 1852: 398.

${ }^{65}$ Courrier des hôtels et Guide du commerce réunis, Mercredi soir, 12 août 1863: 1.

${ }^{66}$ Minute Book 1868-1908, 8 June 1868: 19, TA

${ }^{67}$ Ibid.

${ }^{68}$ New York Daily Tribune (New York) 9 December 1868: 8e.

${ }^{69}$ Almanach des 100,000 adresses des fabricants et commerçants, A. Gambon, (Paris, 1873): 73.

${ }^{70}$ Minute Book 1868-1908, 9 September 1869: 39, TA. Resolution to accept Frodsham's agency.

${ }^{71}$ The Belfast News-Letter (Belfast, Ireland), Friday, 4 November 1870: 1, a. He was resident at the Langham Hotel, in Langham Place, Marylebone, on 2 April 1871. Public Record Office, Census of England and Wales, 1871, RG 10 158; Kelly's Directory (London, 1872) Commercial listing: 1308, Street listing: 159.

${ }^{72}$ Kelly's Directory, London, 1883: Commercial listing, 1311, Street listing, 161.

73 Kelly's Directory, London, 1891, Commercial listing: 1400, Street listing: 163. Kelly's Directory (London, 1892) Commercial listing: 1382, Street listing: 592.

74 "Notes About Town", The Watchmaker, Jeweller and Silversmith XVII, 1, 1 (July 1891): 9b.

75 Ibid.

${ }^{76}$ Personnel Records: Engagements T. \& Co, TA. Personnel Records: Engagements, Box 1869-1906; Book Tiffany \& Co "Engagements of Employees 1895": 88, TA.

${ }^{77}$ Ibid. 3.

${ }^{78}$ Minute Book 1868-1908, 16 April 1873: 71, TA.

${ }^{79}$ Minute Book 1868-1908, 2 October 1874: 58, TA.

${ }^{80}$ Partnership Agreements file. Dated 15 April 1875, a document announcing this change survives in the company archive in French and English.

${ }^{81}$ H.A. Spaulding, My Trip to the Courts of Europe: Report Rendered to Mr. Charles Lewis Tiffany, President of Tiffany and Co. (New York, N.Y., 1897).

82 Tiffany Catalogue, 1879-80, printed 1878, TA: 5.

83 "Notes About Town," 9b.

${ }^{84}$ Westminster Rate Book, St George's, Conduit Ward, 1890, City of Westminster Archive Centre, London; hereafter, CWAC. Kelly's Directory (London, 1891); Westminster Rate Book, St George's, Conduit Ward, 1891, CWAC; Kelly's Directory (London, 1892); Westminster Rate Book, St George's, Conduit Ward, 1892, CWAC; Westminster Rate Book, St George's, Conduit Ward, 1892, CWAC; Surrounding properties did not see an increase in Gross Estimated Rental Value. This increase in rental value for 221/221A was not the result of a general revaluation for the area.

${ }^{85}$ Heydt, Charles L. Tiffany, 27.

${ }^{86}$ Regent Street photograph D135(25), CWAC.

${ }^{87}$ London Register No. 3, Tiffany \& Co, TA.

${ }^{88}$ The Pall Mall Gazette (London), Thursday, 21 December 1899: 11a.

${ }^{89}$ Regent Street: 1898 C138(19 \& 21); 1910 D135(25), CWAC.

${ }^{90}$ Minute Book 1868-1908, 20 November 1905: unnumbered page, TA. Letter dated 4 October 1905 copied into the minutes.

${ }^{91}$ Le Matin (Paris) 12 August 1884, 4b.

${ }^{92}$ Minute Book 1868-1908, 20 November 1905: unnumbered page, TA. Letter dated 4 October 1905 copied into the minutes.

${ }^{93}$ Ibid. Louis Comfort Tiffany was the son of Charles L. Tiffany, one of the two original partners. Charles L. Tiffany died February 1902: Charles L. Tiffany Obituary, New York Times (New York) 19 February 1902: 3, a. Here Louis Comfort Tiffany recognizes the role of Parisian window display as a means to attract a new and wider consumer market: see, Rosalind H. Williams, Dream Worlds: Mass Consumption in Late NineteenthCentury France, (Berkeley, Calif., 1982).

${ }^{94}$ Minute Book 1868-1908, 20 November 1905: unnumbered page, TA. Letter dated 4 October 1905 copied into the minutes.

${ }^{95}$ These roles included sales personnel in the showroom, staff in the diamond office, repair and delivery staff, clerks, porters and packers. Personnel Records: Engagements, Box 1869-1906; Book Tiffany \& Co "Engagements of Employees 1895": 88, TA.

${ }^{96}$ Minute Book 1868-1908, 20 November 1905: unnumbered page, TA. Cable written into minutes.

${ }^{97}$ Minute Book 1868-1908, 20 March 1906: unnumbered page, TA.

98 Ibid.

${ }^{99}$ Ibid.

${ }^{100}$ Ibid. 
${ }^{101}$ La Construction Moderne (Paris) 21 Janvier 1911:197; Daily Trade Record New York (New York) 10 May 1910: 3; The New York Herald (Paris edition) 24 April 1910: 1.

${ }^{102}$ Daily Trade Record New York: 3.

${ }^{103}$ The New York Herald: 1.

104 Ibid.

105 Ibid.

106 Ibid.

${ }^{107}$ Purcell, "Tiffany and Paris," 26-45.

108 Maureen E. Montgomery, Gilded Prostitution: Status, Money and Transatlantic Marriages, 1870-1914 (London, 1989), 2.

${ }^{109}$ The Pall Mall Gazette (London) Tuesday, 20 November 1899: 9c.

${ }^{110}$ London Register No. 3, Tiffany \& Co., London, Sales, TA.

${ }^{111}$ The New York Herald (Paris edition) 24 April 1910: 1.

${ }^{112}$ Angus Maddison, The World Economy: Historical Statistics (Paris and New York, N.Y., 2003), 58, 60.

${ }^{113}$ Ibid: 58-61.

${ }^{114}$ Resseguie, “Alexander Turney Stewart”; Resseguie, “The Decline and Fall”. 